\author{
환경친화적 바이오폴리머인 세균 섬유소의 항균활성과 염색성 \\ 이나리 · 정진하 · 박성보 · 정성윤 ${ }^{1}$ · 황대연 · 김홍성 · 손홍주 ${ }^{*}$ \\ 부산대학교 생명자원과학대학 \\ ${ }^{1)}$ 대구가톨릭대학교 의생명과학과 \\ (2011년 4월 22일 접수; 2011년 5월 11일 수정; 2011년 6월 14일 채택)
}

\title{
Antimicrobial Activity and Coloration of Environment-Friendly Biopolymer, Bacterial Cellulose
}

\author{
Na-Ri Lee, Jin-Ha Jeong, Sung-Bo Park, Seong-Yun Jeong ${ }^{1)}$, Dae-Youn Hwang, \\ Hong-Sung Kim, Hong-Joo Son ${ }^{*}$ \\ College of Natural Resources and Life Science, Pusan National University, Miryang 627-706, Korea \\ ${ }^{1)}$ Department of Medical Life Science, Catholic University of Daegu, Daegu 712-784, Korea
}

(Manuscript received 22 April, 2011; revised 11 May, 2011; accepted 14 June, 2011)

\begin{abstract}
In order to develop bacterial cellulose (BC) with antimicrobial activity against pathogenic microorganisms, silver and chitosan were incorporated into BC, respectively. Experiment results showed that antimicrobial activity against pathogenic microorganisms was improved with increasing silver concentration. Chitosan also showed a direct proportion between its concentration and antimicrobial activity. These results suggest that antimicrobial effects of $\mathrm{BC}$ using silver and chitosan are well proven to be effective. We also tested the stainability of $\mathrm{BC}$ with natural colorant for the application of food industry. Stainability of BC was enhanced with increasing natural colorant concentration. Decolorization of BC stained was observed by dipping it into distilled water with one hour-intervals. As a result, there was no significant difference. Combination of natural colorant-stainability and antibiosis of $\mathrm{BC}$ is expected to be useful in making colored antibiotic $\mathrm{BC}$ in various industrial application areas, considering its antimicrobial activity, high stainability and low decolorization tendency.
\end{abstract}

Key Words : Acetobacter sp., Cellulose, Antimicrobial activity, Coloration

\section{1. 서 론}

섬유소(cellulose)는 자연계에서 다량으로 존재하 는 유기물이며, 포도당이 $\beta-1,4$ 결합으로 이루어진 재 생 가능한 고분자 다당이다. 산업적 응용분야가 넓어

\footnotetext{
${ }^{*}$ Corresponding author : Hong-Joo Son, College of Natural Resources and Life Science, Pusan National University, Miryang 627-706, Korea

Phone: +82-55-350-5544

E-mail: shjoo@pusan.ac.kr
}

제지, 펄프 및 의류 등 다양한 산업에 사용되고 있으 며, 그 소비량이 점차 증가하고 있는 추세이다. 섬유소 는 식물뿐만 아니라 일부 조류, 균류 및 Acetobacter, Agrobacterium, Rhizobium 등의 세균도 합성할 수 있 는 것으로 보고되었다(Delmer, 1999). 식물 섬유소는 펄프화 과정에서 리그닌 등을 화학적으로 제거해야 하며, 이때 많은 에너지와 약품이 소비된다는 측면에 서 비경제적인 과정이다. 그러나 세균 섬유소는 헤미 셀룰로오스, 리그닌과 같은 불순물을 포함하지 않으 므로 화학적 처리공정을 거치지 않고도 고순도의 섬 
유소를 생산할 수 있다는 측면에서 환경친화적인 물 질이다(Yamanaka 등, 1989). 또한 세균 섬유소는 직 경이 식물 섬유소의 $1 / 100 ~ 1 / 500$ 정도밖에 되지 않는 나노 구조체로서 수분 보유력과 성형 가공성이 우수 하고, 고강도 및 고탄력 등의 성질을 가지고 있다 (Cannon과 Anderson, 1991). 이러한 물리화학적 특성 으로 인하여 세균 섬유소는 식이섬유뿐만 아니라 방 탄조끼, 창상 피복제, 인공관절, 정보기록용지 등 고부 가가치 신소재로서 매우 중요한 부분을 차지하고 있 다(Yoshino 등, 1996; Kelmm 등, 2001).

우리의 생활환경 내에는 수많은 미생물들이 존재 하고 있는데, 인체에 위해를 가하는 병원성 미생물에 의한 피해가 발생되면서 미생물 감염으로부터 인간을 보호할 수 있는 지속가능한 항균물질 개발 및 식품이 나 의료용품에 항균성을 부여하기 위한 여러 가지 방 안들이 강구되고 있다. 항균물질에는 다양한 종류가 있으나 인체에 무해하고, 휘발 또는 분해가 일어나지 않는 등 안정성이 뛰어난 무기계 항균 물질인 은 (silver)과 인체에 무독하고, 물질(예를 들면, 섬유)의 기능 저하를 초래하지 않는 등 항균가공제로서 우수 한 생분해성과 환경친화성을 갖는 천연 고분자 물질 인 키토산이 대표적이다(Lim 등, 2001). 현재, 창상 피 복제의 경우 게의 껍질에서 채취한 키틴을 원료로 하 여 이것을 습식 방사한 섬유 제조에 대한 연구가 진행 되고 있다(Kuruyanagi와 Shioya, 1996). 은은 오래전 부터 식품에 사용할 정도로 인체에 무해하며, $1 \mathrm{ppm}$ 이하의 낮은 농도에서도 살균효과를 갖는 것으로 알 려져 있다(Gaisforda 등, 2009). 현재, 다양한 유도체 를 결합한 은 이온 복합물에 대한 항균 연구가 활발하 게 진행되고 있는데(Stefano 등, 2001), 특히 은 복합 물은 항균 활성뿐만 아니라 임상적으로 미생물 감염 에 의한 상처 치료에도 효과를 가지는 것으로 보고되 어 있다(Wright 등, 1999; Marone 등, 1998). 최근 들 어 세균 섬유소에 은을 첨가하여 의료분야에 적용 가 능한 피복재의 제조 및 그 이용 가능성에 대한 연구가 시작되고 있다.

천연염색은 자연계에 존재하는 동식물 및 광물로 부터 색소를 얻고 이것을 이용하여 염색하는 것을 말 한다. 특유의 은은하고 차분한 합성염료와 달리 천염 염료는 미려하고 감성적인 색감을 창출할 수 있고, 인
체에 무해하며 환경오염을 유발하지 않는 친환경적인 염색이 가능할 뿐 아니라 항균 및 항알레르기성 등의 기능성을 부여할 수 있는 장점을 갖고 있어 이에 대한 연구가 많이 진행되고 있다(Choi와 Jung, 1997). 최근 에는 천연염색에 많이 사용되는 치자색소를 목질계 섬유소 섬유에 착색시키는 연구와 치자색소의 염색성 및 항균성에 관한 연구가 수행되기도 하였다(Cho와 Jang, 1993).

본 실험에서는 세균 섬유소의 의료 및 식품에의 적 용을 위한 기초자료를 확보하고자 키토산 또는 은 용 액에 침지시킨 세균 섬유소의 병원성 미생물에 대한 항균효과를 검토하였으며, 천연 식용색소인 파프리카 색소와 치자색소 등을 이용하여 세균 섬유소의 염색 성을 조사하였다.

\section{2. 재료 및 방법}

\section{1. 균주 및 배양조건}

본 실험에 사용된 균주는 한국의 전통식초로부터 분리 및 동정된 Acetobacter sp. V6이었다(Jung 등, 2010). 균주의 보존과 세균 섬유소 생산에 사용된 HS 배지의 조성은 glucose $2 \%$, yeast extract $0.5 \%$, polypeptone $0.5 \%, \mathrm{Na}_{2} \mathrm{HPO}_{4} \cdot 12 \mathrm{H}_{2} \mathrm{O} 0.675 \%$, citric acid $0.115 \%(\mathrm{pH} 6)$ 이었다. 전배양은 $50 \mathrm{ml}$ 의 $\mathrm{HS}$ 배 지가 함유된 250-ml 용량의 삼각 플라스크에 보존중 인 균주 한 백금이를 접종하여 $30^{\circ} \mathrm{C}$ 에서 72 시간동안 정치배양하였다. 전배양 후, 형성된 섬유소 막 (pellicle)으로부터 세포를 유리시키기 위하여 10 분간 강하게 진탕한 후, 멸균된 거즈로 여과하여 세균 현탁 액을 회수하였다. 이 세균 현탁액 $5 \%$ 를 HS 배지 50 $\mathrm{ml}$ 가 함유된 $\operatorname{vial}\left(\right.$ 단면적 $9 \mathrm{~cm}^{2}$ )에 접종하여 $30^{\circ} \mathrm{C}$ 에서 7일간 정치배양하였다.

\section{2. 은 및 키토산을 이용하여 조제된 세균 섬유소의 항균능} 조사

세균 섬유소를 동일한 크기로 자른 다음 $\mathrm{AgNO}_{3}$ 의 농도가 $0.001-0.1 \%$ 로 조절된 은 용액에 각각 1 시간 동안 침지시켰다. 세균 섬유소의 과도한 은 용액은 여 과지를 이용하여 흡수 제거한 후, $105^{\circ} \mathrm{C}$ 에서 12 시간 동안 건조하였다. 이렇게 처리된 세균 섬유소를 병원 성 미생물이 도말된 nutrient agar plate에 올려놓고 30 
${ }^{\circ} \mathrm{C}, 24$ 시간 동안 배양한 후, 미생물의 생육이 저지된 투명대를 관찰하였다. 이때 사용한 병원성 미생물은 Candida albicans, Escherichia coli, Staphylococcus aureus, Listeria monocytogenes 이었으며, Brain Heart Infusion broth에 각 균주를 접종하여 $30^{\circ} \mathrm{C}, 200 \mathrm{rpm}$ 에서 24 시간동안 배양한 후, 각 $100 \mu$ 씩 nutrient agar plate에 접종하였다. 또한 동일한 크기로 자른 세 균 섬유소를 0.1-1.5\%로 조절된 키토산 용액에 각각 1 시간 동안 침지시켰다. 이후 과정은 상기와 동일하 였다.

\section{3. 천연 식용색소를 이용한 세균 섬유소 염색성 조사}

세균 섬유소를 천연 식용색소의 농도가 $0.1-0.4 \%$ 로 각각 조절된 색소 용액에 1 시간 동안 침지시킨 후, 염색성을 육안으로 관찰하였다. 또한 HS 배지에 천연 식용색소를 0.1-0.4\%가 되도록 각각 첨가하여 배양 한 후, 생성된 세균 섬유소의 염색성을 관찰하였다. 염색된 각 세균 섬유소를 1 시간 간격으로 3 시간까지 증류수로 세척하여 탈색 정도를 관찰하였다. 이때 사 용한 천연 식용색소는 파프리카색소 $\mathrm{WS}$, 치자블루 $\mathrm{SB}-50$, 치자옐로우 $1500 \mathrm{CR}$, 치자그린 $\mathrm{BC}$, 치자레드 $\mathrm{BR}$ 이었다.

\section{4. 세균 섬유소의 정제}

생산된 세균 섬유소를 회수하여 물로 충분히 세척 한 후, $0.5 \mathrm{~N} \mathrm{NaOH}$ 용액에 침지하여 $90^{\circ} \mathrm{C}$ 에서 2 시간 동안 처리함으로써 세포를 용해시켰다. 이들을 중성 이 될 때까지 증류수로 세척한 후, 세균 섬유소를 회수 하였다(Embuscado 등, 1996).

\section{3. 결과 및 고찰}

\section{1. 은을 이용하여 생성된 세균 섬유소의 항균효과}

각 농도의 은 용액에 침지시킨 세균 섬유소의 항균 능을 조사한 결과는 Table 1 및 Fig. 1에서 보는바와 같다. 은의 농도가 높아질수록 병원성 미생물에 대한 생육 저지대가 컸으며, 피검균주에 따라서 생육 저지 대의 크기는 차이가 났다. 특히 C. albicans 의 경우, 은 의 농도가 높을수록 생육 저지대의 직경이 커졌는데, $0.1 \%$ 에서 가장 크게 나타났다. E. coli의 경우, 0.001$0.01 \%$ 의 은 농도에서 동일한 크기의 생육 저지대를
나타내었으며, $0.03 \%$ 부터 생육 저지대가 커졌다. $S$. aureus와 L. monocytogenes 역시 은의 농도가 높아질 수록 생육 저지대의 직경이 커지는 것을 알 수 있었다. 현재 세균 섬유소는 수분 보유력이 높아 창상 피복제 로서 연구 중에 있다(Ciechanska, 2002). 따라서 세균 섬유소에 항균능이 부여된다면 환부 치료과정 중 발 생할 수 있는 감염성 병원균에 의한 상처 악화를 예방 할 수 있을 것으로 판단된다.

Table 1. Antimicrobial activity of silver solution-dipped bacterial cellulose

\begin{tabular}{lcccccc}
\hline \multirow{2}{*}{ Test strain } & \multicolumn{6}{c}{ Concentration (\%) } \\
\cline { 2 - 7 } & 0.001 & 0.005 & 0.01 & 0.03 & 0.05 & 0.1 \\
\cline { 2 - 6 } & 0.9 & 1.1 & 1.3 & 1.6 & 1.7 & 1.9 \\
\hline C. albicans & 0.9 & 0.9 & 0.9 & 1.1 & 1.3 & 1.4 \\
E. coli & 0.8 & 1.1 & 1.2 & 1.3 & 1.4 & 1.5 \\
S. aureus & 0.8 & 0.8 & 1.0 & 1.1 & 1.2 & 1.3 \\
L. monocytogenes &
\end{tabular}
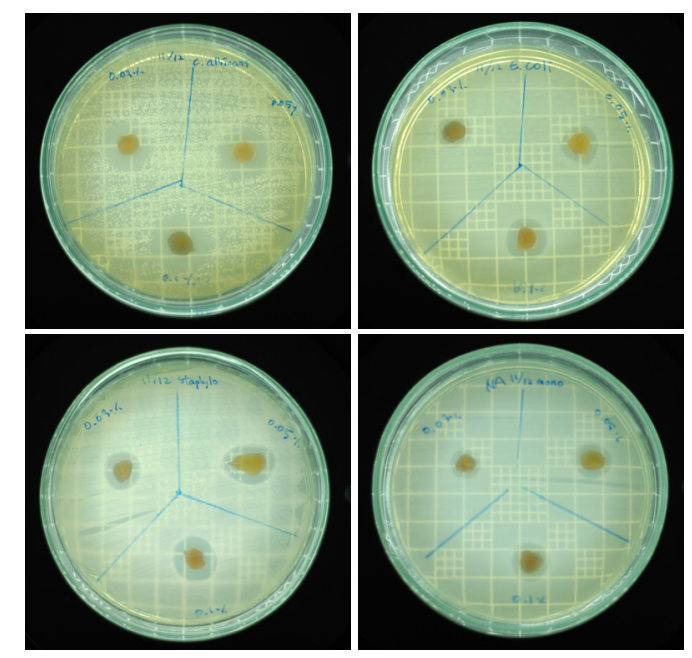

Fig. 1. Antimicrobial activities of silver solution-dipped bacterial cellulose against $C$. albicans (upper left), E. coli (upper right), S. aureus (lower left) and $L$. monocytogenes (lower right).

\section{2. 키토산을 이용하여 생성된 세균 섬유소의 항균효과}

각 농도의 키토산 용액에 침지한 세균 섬유소의 항 균능을 조사한 결과는 Table 2 및 Fig. 2에서 보는바와 같다. 즉, 키토산 농도가 높아질수록 생육 저지대의 직 경도 크게 나타났다. 키토산 $0.1 \%$ 의 농도에서는 항균 
능이 나타나지 않았으며, 농도가 높을수록 미세하지 만 항균능을 나타내었다. 그러나 전체적으로 은과 비 교시 항균효과는 크지 않았다.

Table 2. Antimicrobial activity of chitosan solution-dipped bacterial cellulose

\begin{tabular}{lcccc}
\hline \multirow{2}{*}{\multicolumn{1}{c}{ Test strain }} & \multicolumn{4}{c}{ Concentration (\%) } \\
\cline { 2 - 5 } & 0.1 & 0.5 & 1.0 & 1.5 \\
\cline { 2 - 5 } & - & 0.85 & 0.9 & 1.0 \\
\hline \hline C. albicans & - & 0.82 & 0.9 & 1.1 \\
E. coli & - & 0.83 & 1.0 & 1.1 \\
S. aureus & - & 0.85 & 0.9 & 1.0 \\
L. monocytogenes & - & &
\end{tabular}
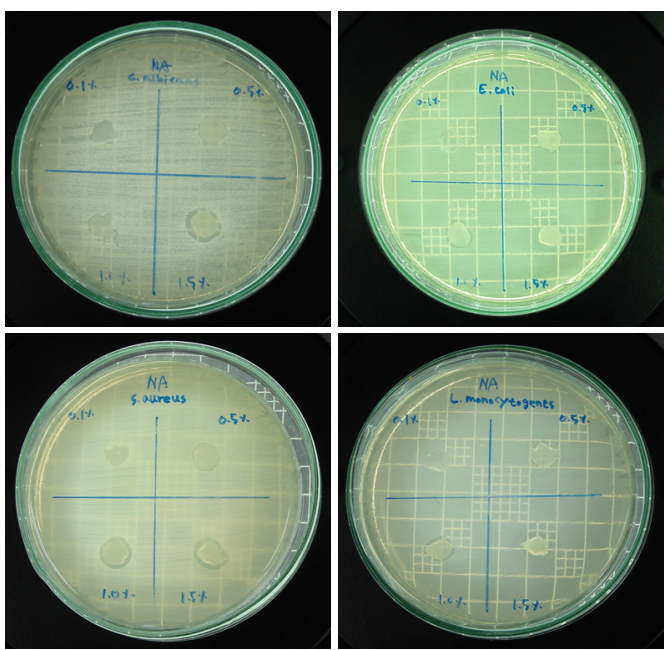

Fig. 2. Antimicrobial activities of chitosan solution-dipped bacterial cellulose against $C$. albicans (upper left), E. coli (upper right), $S$. aureus (lower left) and $L$. monocytogenes (lower right).

\section{3. 천연 식용색소 용액에 침지한 세균 섬유소의 염색성}

세균 섬유소를 천연색소의 농도가 $0.1 \%$ 에서 $0.4 \%$ 까지 각각 조절된 색소 용액에 1 시간 동안 침지시킨 후, 염색성을 관찰한 결과는 Fig. 3 에서 보는바와 같이 농도가 높을수록 짙게 염색 되었다. 한편, 각 농도의 용액에서 염색한 세균 섬유소들을 증류수로 세척하여 탈색시킨 결과, 시간이 경과 할수록 약간씩 탈색되었 으나 그 수준은 미미하였다(미제시).

$\mathrm{HS}$ 배지에 각 천연색소를 $0.1 \%$ 에서 $0.4 \%$ 까지 각 각 농도별로 첨가하여 배양한 후, 생성된 세균 섬유소

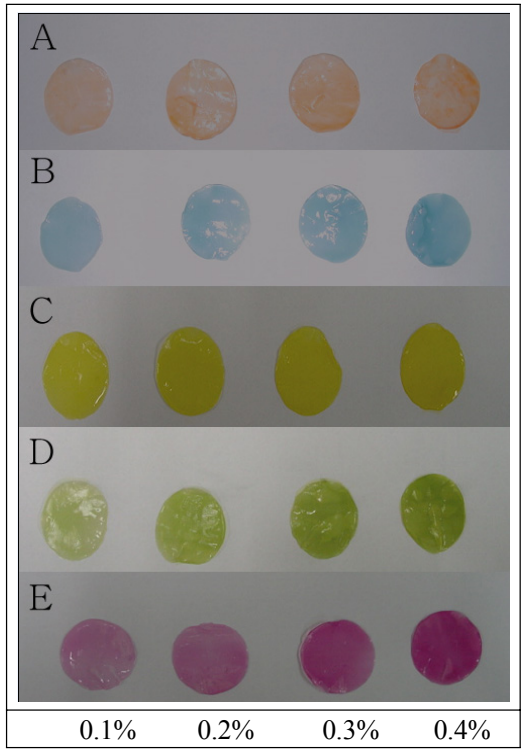

Fig. 3. Effect of natural colorant on dyeing degree of bacterial cellulose produced by Acetobacter sp. V6. A; Paprika powder(WS), B; Gardenia colorant(SB-50), C; Gardenia colorant(1500CR), D; Gardenia colorant (BC), E; Gardenia colorant(BR).

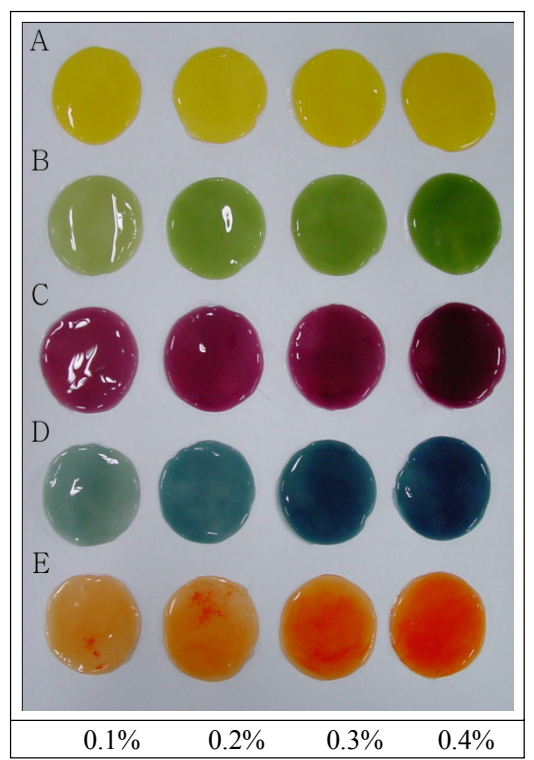

Fig. 4. Colorization of bacterial cellulose from HS medium containing natural colorant. A; Gardenia colorant (1500CR), B; Gardenia colorant (BC), C; Gardenia colorant (BR), D; Gardenia colorant (SB-50), E; Paprika powder (WS). 
의 염색 정도를 조사한 결과는 Fig. 4에서 보는바와 같 다. 치자옐로우를 제외한 모든 색소에서 농도가 높을 수록 진하게 염색되었다. 특히, 치자옐로우 $1500 \mathrm{CR}$ 경우, 농도에 따른 염색도의 차이가 거의 없었다. 천연 식용색소를 이용하여 직접 염색한 앞의 경우보다 염 색도가 높았는데, 이것은 배양과정을 통하여 배지에 존재하는 천연 식용색소 분자가 생성되는 세균 섬유 소의 나노 미세망상구조 속으로 흡착하여 들어간 것 에 기인하는 것으로 판단되었다. 한편, 각 농도의 천연 식용색소가 첨가된 배지에서 생성된 세균 섬유소들을 증류수로 세척하여 탈색시킨 결과, 각 색소마다 아주 미소한 탈색은 발생하였으나 상기 침지 실험과 달리 염색도가 거의 탈색 전 수준으로 유지되었는데, $0.3 \%$ 천연색소가 첨가된 배지에서 생성된 세균 섬유소의 탈색 정도를 관찰한 결과는 Fig. 5에서 보는바와 같다. 세균 섬유소는 부드러운 질감과 높은 식이섬유 함량 을 가지고 있기 때문에 일부 국가에서 후식으로 식용 하고 있다(Okiyama 등, 1992). 만약 투명한 백색의 세 균 섬유소에 각종 색상을 부여할 수 있다면 그 외관을 개선시킬 수 있을 뿐만 아니라 다양한 식품의 장식물 로서 이용될 수 있을 것이며, 소비자들의 구매 욕구 또 한 증가시킬 수 있을 것이다(Sheu 등, 2000).

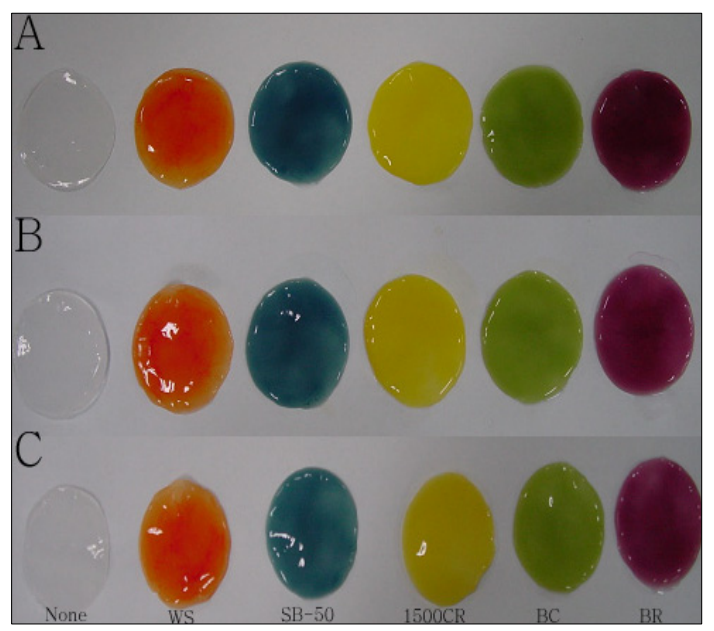

Fig. 5. Decolorization of bacterial cellulose from HS medium containing natural colorant. Bacterial cellulose stained was dipped in the distilled water and then was kept at room temperature for 1-3 hours. A; after 1 hour, B; after 2 hour, C; after 3 hour.

\section{5. 세균 섬유소의 투명도 및 마스크 팩 이용}

세균 섬유소를 회수하여 세균을 제거한 후, 투명도 를 관찰한 결과는 Fig. 6에서 보는 바와 같이 완전히 투명함을 알 수 있었다. 이러한 투명성은 세균 섬유소 를 창상피복제 등 의료용으로 사용할 경우, 환부 상태 관찰을 용이하게 할 수 있음을 시사한다(Kelmm 등, 2001).

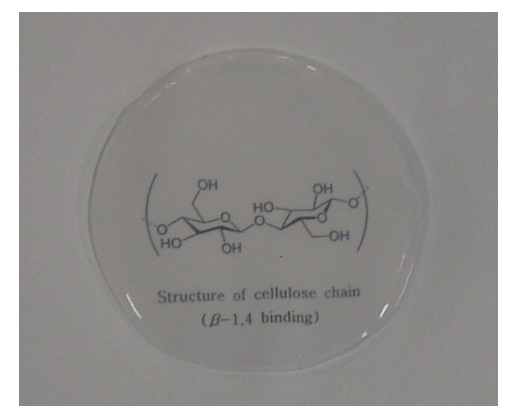

Fig. 6. Transparency of bacterial cellulose.

또한 얼굴의 피부보습 마스크로서의 가능성을 확 인하기 위하여 생성된 세균 섬유소를 마스크 팩으로 가공하여 직접 착용한 결과는 Fig. 7에서 보는 바와 같 다. 즉, 마스크 팩으로 이용할 수 있을 정도로 넓고 큰 세균 섬유소를 생산할 수 있었으며, 대단히 견고함을 유지한다는 것을 확인할 수 있었다. 또한, 마스크 팩을 쓰고 있는 동안 수분이 오랫동안 유지되어서 보수력 이 뛰어난 것으로 추정되었으므로 마스크 팩으로 이 용 잠재력이 있는 것으로 판단되었다.

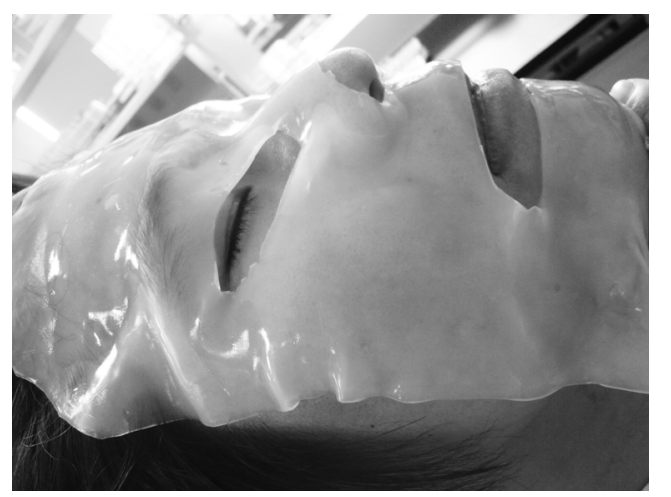

Fig. 7. Utilization of bacterial cellulose as the moisturizing mask pack. 


\section{4. 결 론}

본 연구에서는 Acetobacter sp. V6에 의해 생산된 세균 섬유소에 병원성 미생물에 대한 항균능을 부여 하기 위하여 은과 키토산 침지 실험을 실시하였다. 또 한, 천연색소를 이용하여 세균 섬유소의 염색성을 관 찰하여 세균 섬유소의 식품산업에의 응용 가능성을 알아보고자 하였다. 실험 결과, 은의 병원성 미생물에 대한 항균 활성은 농도가 높아질수록 증가함을 확인 할 수 있었고, 키토산의 경우 은과 마찬가지로 병원성 미생물에 대한 항균 활성이 농도에 비례하여 점차 향 상됨을 알 수 있었다. 또한 각 농도의 천연색소에 세균 섬유소를 침지하거나 배지 성분으로 첨가한 후 생성 된 세균 섬유소의 염색성을 조사한 결과, 색소의 농도 가 높을수록 염색성은 증가하였으며, 이를 증류수에 담구어 1 시간 간격으로 탈색도를 관찰하였으나 크게 차이는 없음을 알 수 있었다. 위 결과를 통해 은과 키 토산은 세균 섬유소에 항균능을 부여한다는 것을 확 인할 수 있었으며, 천연색소를 통한 세균 섬유소 염색 성 또한 색소의 흡수력이 높고 탈색이 잘 되지 않음을 확인할 수 있었다.

\section{참 고 문 헌}

Cannon, R. E., Anderson, S. M., 1991, Biogenesis of bacterial cellulose. Crit. Rev. Microbiol., 17, 435-447.

Cho, K. R., Jang, J. D., 1993, Studies on the natural dyes(VI)-dyeing of cellulose fibers by color of Cape Jasmin, J. Pusan Women's Juni. Coll., 36, 323-334.

Choi, S. C., Jung, J. S., 1997, Studies of antimicrobial from extracts of Impatiens balsamina (I), J. Kor. Textile Sci. Eenginee., 34, 393-399.

Ciechanska, D., 2002, Multifunctional bacterial cellulose/ chitosan composite materials for medical applications, Fib. Texti. East. Eur., 12, 69-72.

Delmer, D. P., 1999, Cellulose biosynthesis: exciting times for a difficult field of study, Annu. Rev. Plant Physiol. Plant Mol. Biol., 50, 245-276.

Embuscado, M. E., BeMiller, J. N., Marks, J. S., 1996, Isolation and partial characterization of cellulose produced by Acetobacter xylinum, Food Hydrocoll., 10, 75-82.

Gaisforda, S., Beezera, A. E., Bishopb, A. H., Walkerc, M., Parsonsc, D., 2009, An in vitro method for the quantitative determination of the antimicrobial efficacy of silver-containing wound dressings, Int. J. Pharm., 366, 111-116.

Jung, H. I., Lee, O. M., Jeong, J. H., Jeon, Y. D., Park, K. H., Kim, H. S., An, W. G., Son, H. J., 2010, Production and characterization of cellulose by Acetobacter sp. V6 using a cost-effective molasses-corn steep liquor medium, Appl. Biochem. Biotechnol., 162, 486-497.

Kelmm, D., Schumann, D., Udhard, U., Marsch, S., 2001, Bacterial synthesized cellulose-artficial blood vessels for microsurgery, Prog. Polym. Sci., 26, 1561-1603.

Kuroyanagi, Y., Shioya, N., 1996, Advanced in wound dressing and cultured skin substitute, Kitasato Univ. Press, Tokyo, 32-77.

Lim, Y. T, Choi, H. K., Ahn, Y. H., 2001, Antimicrobial activity assessment of functional plastics which contained Ag-hydroxyapatite agent, Kor. J. Biotechnol. Bioeng., 16, 123-127.

Marone, P., Monzillo, V., Perversi, L., Carretto, E., 1998, Comparative in vitro activity of silver sulfadiazine, alone and in combination with cerium nitrate, against staphylococci and gram-negative bacteria, J. Chemother., 10, 17-21.

Okiyama, A., Shirae, H., Kano, H., Yamanaka, S., 1992, Bacterial cellulose. Two-stage fermentation process for cellulose production by Acetobacter aceti, Food Hydrocoll., 6, 471-477.

Sheu, F., Wang, C. L., Shyu, Y. T., 2000, Fermentation of Monascus purpureus on bacterial cellulose-nata and the color stability of Monascus-nata complex, J. Food, Sci., 65, 342-345.

Stefano, B,, Jean, H. U., Ralph, B. D., Robert, J. S., 2001, Prolonged antimicrobial activity of a catheter containing chlorhexidine silver sulfadiazine extends protection against catheter infections in vivo, Antimicrob. Agents Chemother., 45, 1535-1538.

Wright, J. B., Lam, K., Hansen, D., Burrell, R. E., 1999, Efficacy of topical silver against fungal burn wound pathogens, Am. J. Infect. 27, 344-350. 
Yamanaka, S., Watanabe, K., Kitamura, N., Iguchi, M., Mitsuhashi, S., Nishi, Y., Uryu, M., 1989, The structure and mechanical properties of sheets prepared from bacterial cellulose, J. Mat. Sci., 24,
3141-3145.

Yoshino, T., Asakura, T., Toda, K., 1996, Cellulose production by Acetobacter pasteurianus on silicone membrane, J. Ferment. Bioeng., 81, 32-36. 